\section{KEWENANGAN PEJABAT PENGAWAS LINGKUNGAN HIDUP MENURUT UNDANG- UNDANG NOMOR 32 TAHUN 2009 TENTANG PERLINDUNGAN DAN PENGELOLAAN LINGKUNGAN HIDUP ${ }^{1}$ \\ Oleh: Juvisher Vigoh Rivaldo Sarajar ${ }^{2}$}

Tommy M. R. Kumampung ${ }^{3}$ Marthin L. Lambonan ${ }^{4}$

\begin{abstract}
ABSTRAK
Penelitian ini dialkukan dengan tujuan untuk mengetahui bagaimana kewenangan pejabat pengawas lingkungan hidup menurut UndangUndang Nomor 32 Tahun 2009 Tentang Perlindungan Dan Pengelolaan Lingkungan Hidup dan bagaimana penetapan pejabat pengawas lingkungan hidup. Dengan menggunakan metode penelitian yuridis normatif, disimpulkan: 1 . Kewenangan pejabat pengawas lingkungan hidup seperti melakukan pemantauan, meminta keterangan, membuat salinan dari dokumen dan/atau membuat catatan yang diperlukan, memasuki tempat tertentu, memotret, membuat rekaman audio visual, mengambil sampel, memeriksa peralatan, memeriksa instalasi dan/atau alat transportasi dan/atau menghentikan pelanggaran tertentu. Penanggung jawab usaha dan/atau kegiatan dilarang menghalangi pelaksanaan tugas pejabat pengawas lingkungan hidup. 2. Penetapan Pejabat Pengawas Lingkungan hidup dilaksanakan oleh Menteri, gubernur, atau bupati/walikota sesuai dengan kewenangannya wajib melakukan pengawasan terhadap ketaatan penanggung jawab usaha dan/atau kegiatannya dan pengawasan kepada pejabat/instansi teknis termasuk menetapkan pejabat pengawas lingkungan hidup yang merupakan pejabat fungsional dalam perlindungan dan pengelolaan lingkungan hidup.
\end{abstract}

Kata kunci: Kewenangan, Pejabat, Pengawas, Lingkungan Hidup, Perlindungan Dan Pengelolaan Lingkungan Hidup

\footnotetext{
${ }^{1}$ Artikel Skripsi

2 Mahasiswa pada Fakultas Hukum Unsrat, NIM. 16071101380

${ }^{3}$ Fakultas Hukum Unsrat, Magister IImu Hukum

${ }^{4}$ Fakultas Hukum Unsrat, Magister Ilmu Hukum
}

\section{PENDAHULUAN}

\section{A. Latar Belakang}

Problem lingkungan hingga kini terus menjadi isu yang selalu aktual dan belum tertanggulangi, terlebih di era reformasi yang tak luput pula dari tuntutan demokratisasi dan transparansi. Dalam rangka mengantisipasi kian meluasnya dampak kontraproduktif terhadap lingkungan khususnya akibat perkembangan dunia industri yang pesat maka penegakan hukum di bidang lingkungan hidup menjadi mutlak diperlukan. Segenap stakeholders harus mempunyai tekad untuk memelihara lingkungan dari kemerosotan fungsi yang senantiasa mengancam kehidupan masa kini dan masa mendatang. Hukum lingkungan dengan demikian, mempunyai peran yang sangat urgen dalam membantu mewujudkan pembangunan berkelanjutan. ${ }^{5}$

Indonesia mempunyai kekayaan keanekaragaman hayati dan sumber daya alam yang melimpah. Kekayaan itu perlu dilindungi dan dikelola dalam suatu sistem perlindungan dan pengelolaan lingkungan hidup yang terpadu dan terintegrasi antara lingkungan laut, darat, dan udara berdasarkan wawasan Nusantara. Indonesia juga berada pada posisi yang sangat rentan terhadap dampak perubahan iklim. Dampak tersebut meliputi turunnya produksi pangan, terganggunya ketersediaan air, tersebarnya hama dan penyakit tanaman serta penyakit manusia, naiknya permukaan laut, tenggelamnya pulau pulau kecil, dan punahnya keanekaragaman hayati. $^{6}$

Ketersediaan sumber daya alam secara kuantitas ataupun kualitas tidak merata, sedangkan kegiatan pembangunan membutuhkan sumber daya alam yang semakin meningkat. Kegiatan pembangunan juga mengandung risiko terjadinya pencemaran dan kerusakan lingkungan. Kondisi ini dapat mengakibatkan daya dukung, daya tampung, dan produktivitas lingkungan hidup menurun yang pada akhirnya menjadi beban sosial. Perlindungan dan pengelolaan lingkungan

\footnotetext{
${ }^{5}$ Ibid. hlm. 174.

${ }^{6}$ I. Putu Sastra Wibawa. Politik Hukum Perlindungan Dan Pengelolaan Lingkungan Menuju Ekokrasi Indonesia (Legal Politic Of Protection And Management Oenvironment Heading To Indonesia Ecocracy). Kanun Jurnal IImu Hukum.Vol. 18, No. 1, (April, 2016), pp. 51-68. hlm. 52.
} 
hidup menuntut dikembangkannya suatu sistem yang terpadu berupa suatu kebijakan nasional perlindungan dan pengelolaan lingkungan hidup yang harus dilaksanakan secara taat asas dan konsekuen dari pusat sampai ke daerah. Penggunaan sumber daya alam harus selaras, serasi, dan seimbang dengan fungsi lingkungan hidup. Sebagai konsekuensinya, kebijakan, rencana, dan/atau program pembangunan harus dijiwai oleh kewajiban melakukan pelestarian lingkungan hidup dan mewujudkan tujuan pembangunan berkelanjutan. ${ }^{7}$

\section{B. Rumusan Masalah}

1. Bagaimanakah kewenangan pejabat pengawas lingkungan hidup menurut Undang-Undang Nomor 32 Tahun 2009 Tentang Perlindungan Dan Pengelolaan Lingkungan Hidup.

2. Bagaimanakah penetapan pejabat pengawas lingkungan hidup ?

\section{Metode Penelitian}

Metode penelitian hukum yang digunakan dalam penyusunan penulisan ini, ialah metode penelitian hukum normatif. Data sekunder yang digunakan diperoleh melalui studi kepustakaan. Data sekunder terdiri dari bahan hukum primer ialah: peraturan perundang-undangan di bidang perlindungan dan pengelolaan lingkungan hidup dan bahan hukum sekunder terdiri dari literatur-literatur, jurnal hukum dan artikel hukum yang sesuai dengan penulisan ini serta bahan hukum tersier terdiri dari kamus umum dan kamus hukum untuk menjelaskan pengertian dari istilah-istilah hukum yang digunakan dalam penulisan ini.

\section{PEMBAHASAN}

\section{A. Kewenangan Pejabat Pengawas Lingkungan Hidup Menurut Undang-Undang Nomor 32 Tahun 2009 Tentang Perlindungan Dan Pengelolaan Lingkungan Hidup \\ Undang-Undang Nomor 32 Tahun 2009 \\ Tentang Perlindungan Dan Pengelolaan Lingkungan Hidup. Pasal 74 ayat: \\ (1) Pejabat pengawas lingkungan hidup sebagaimana dimaksud dalam Pasal 71 ayat (3) berwenang:}

\footnotetext{
${ }^{7}$ Ibid. hlm. 52.
}

a. melakukan pemantauan;

b. meminta keterangan;

c. membuat salinan dari dokumen dan/atau membuat catatan yang diperlukan;

d. memasuki tempat tertentu;

e. memotret;

f. membuat rekaman audio visual;

g. mengambil sampel;

h. memeriksa peralatan;

i. memeriksa instalasi dan/atau alat transportasi; dan/atau

j. menghentikan pelanggaran tertentu.

(2) Dalam melaksanakan tugasnya, pejabat pengawas lingkungan hidup dapat melakukan koordinasi dengan pejabat penyidik pegawai negeri sipil.

(3) Penanggung jawab usaha dan/atau kegiatan dilarang menghalangi pelaksanaan tugas pejabat pengawas lingkungan hidup.

Pasal 75. Ketentuan lebih lanjut mengenai tata cara pengangkatan pejabat pengawas lingkungan hidup dan tata cara pelaksanaan pengawasan sebagaimana dimaksud dalam Pasal 71 ayat (3), Pasal 73, dan Pasal 74 diatur dalam Peraturan Pemerintah.

Pengawasan merupakan suatu alat di dalam bersikap yang positif, artinya bukan kesalahan yang dicari, melainkan maksud pengawasan yang sesungguhnya ialah menjaga agar apa yang telah direncanakan berjalan dengan baik, tegasnya diusahakan jangan sampai terjadi kesalahan-kesalahan dan kekurangankekurangan di dalam pelaksanaan rencana tersebut. ${ }^{8}$

Dalam suatu negara hukum, pengawasan terhadap tindakan pemerintahan dimaksudkan agar pemerintah dalam menjalankan aktivitasnya sesuai dengan norma-norma hukum, sebagai suatu upaya preventif, dan juga dimaksudkan untuk mengembalikan pada situasi sebelum terjadinya pelanggaran normanorma hukum, sebagai upaya represif. Di samping itu, yang terpenting adalah bahwa pengawasan ini diupayakan dalam rangka memberikan perlindungan hukum bagi masyarakat. Pengawasan adalah salah satu

\footnotetext{
${ }^{8}$ Rocky Marbun, Deni Bram, Yuliasara Isnaeni dan Nusya A., Kamus Hukum Lengkap (Mencakup Istilah Hukum \& Perundang-Undangan Terbaru, Cetakan Pertama, Visimedia, Jakarta. 2012. hlm. 229-230.
} 
yang bersifat kodrati. Pengawasan diperlukan dalam kehidupan manusia dan dalam kehidupan organisasi. ${ }^{9}$

Pengawasan dilakukan bukan karena kurang kepercayaan atau untuk mencari-cari siapa yang salah. Tetapi untuk memahami apa yang salah demi perbaikan di masa yang akan datang. Jika pengawasan seperti itu terlaksana, maka semua perencanaan dan peraturan akan berjalan dengan baik, dalam artian tidak ada gangguan dan rongrongan terhadap pelaksanaannya. Hal ini akan menciptakan suasanan tenang, aman dan berkeadilan. ${ }^{10}$

Peningkatan fungsi pengawasan melekat di lingkungan aparat pemerintah bertolak dari motivasi untuk meningkatkan efisiensi dan efektivitas pelaksanaan tugas-tugas umum pemerintahan dan pembangunan, dengan cara sedini mungkin mencegah terjadinya kekurangan dan kesalahan dalam merencanakan dan melaksanakan tugas-tugas di lingkungan organisasi kerja masing-masing. Pengawasan adalah segenap kegiatan untuk meyakinkan dan menjamin bahwa pekerjaanpekerjaan dilakukan sesuai dengan rencana yang telah ditetapkan, kebijaksanaankebijaksanaan yang telah digariskan dan perintah-perintah yang telah diberikan dalam rangka pelaksanaan rencana tersebut. ${ }^{11}$

Pejabat Pengawas lingkungan Hidup (PPLH) dan Pejabat Pengawas Lingkungan Hidup Daerah (PPLHD) dalam melaksanakan tugasnya diberikan kewenangan sebagaimana tersebut diatas dilindungi oleh undang-undang sebagaimana diatur dalam Pasal 115 UndangUndang nomor 32 tentang perlindungan dan pengelolaan lingkungan hidup disebutkan " setiap orang yang dengan sengaja mencegah, menghalang-halangi atau mengagalkan pelaksanaan tugas pejabat pengawas lingkungan hidup dan/atau pejabat penyidik pegawai negeri sipil dipidana dengan pidana penjara paling lama 1 (satu) tahun dan denda paling banyak Rp.500.000.000 (lima ratus juta rupiah). ${ }^{12}$

\footnotetext{
9 Sarwoto. Dasar-dasar Organisasi dan Manajemen, Ghalia Indonesia. Jakarta. 1994. hlm. 9.

${ }^{10}$ Ibid.

${ }^{11}$ Nawawi, Hadari. Pengawasan Melekat di Lingkungan Aparatur Pemerintah. Gelora Aksara Pratama, Jakarta. 1992. hlm. 7.

12 http://portal.bangkabaratkab.go.id/content/pejabatpengawas-lingkungan-hidup-daerah-pplhd?. Artikel.
}

Undang-Undang Nomor 32 tentang Perlindungan Dan Pengelolaan Lingkungan Hidup juga mengamanatkan selain pihak lain yang menghalang-halangi tugas seorang pejabat pegawas lingkungan hidup (PPLH) dan seorang pejabat pengawas lingkungan hidup daerah (PPLHD) dan pejabat yang berwenang mendapat sanksi, maka seorang pengawas pun mempunyai kewajiban dan sanksi pidana sebagaimana diatur dalam pasal 112 UU/32 2009 yang berbunyi ' setiap pejabat yang dengan sengaja tidak melakukan pengawasan terhadap ketaatan penanggung jawab usaha dan/atau kegiatan terhadap peraturan perundang-undangan dan izin lingkungan sebagaimana dimaksud dalam pasal 71 dan pasal 72 , yang mengakibatkan terjadinya pencemaran dan/atau kerusakan lingkungan hidup yang mengakibatkan hilangnya nyawa manusia, dipidana dengan pidana penjara paling lama 1 (satu) tahun atau denda paling banyak 500.000 .000 (lima ratus juta rupiah).

Pengawasan lingkungan hidup merupakan salah satu instrumen penegakan hukum dan merupakan mandat UU Nomor 32 tahun 2009 tentang Perlindungan dan Pengelolaan Lingkungan Hidup dimana dalam pasal tersebut Menteri/ Gubernur/Bupati/Walikota mengangkat dan menetapkan pejabat pengawas lingkungan hidup (PPLH) dan pejabat pengawas lingkungan hidup daerah (PPLHD) merupakan jabatan fungsional karena diharapkan seorang PPLH/PPLHD sebagai pengawas lingkungan hidup dapat fokus dan lebih mandiri dan mempunyai tanggung jawab dalam melaksanakan tugasnya.

Pengawasan lingkungan hidup (enviromental inspection) adalah merupakan tugas yang dimandatkan oleh UU No 32/2009 kepada Gubernur/Bupati/Walikota melalui instansi yang membidangi perlindungan dan pengelolaan lingkungan hidup untuk melakukan pengawasan lingkungan hidup sedangkan pengawasan yang dilakukan oleh Pejabat Pengawas Lingkungan Hidup Daerah (PPLHD) adalah merupakan pendelegasian pengawasan sesuai Pasal 71 UU No 32/2009. ${ }^{13}$

\footnotetext{
Pejabat Pengawas Lingkungan Hidup Daerah (PPLHD) Diakses 3/21/2020 10:05 Wita.

${ }_{13}$ http://portal.bangkabaratkab.go.id/content/pejabatpengawas-lingkungan-hidup-daerah-pplhd?. Artikel.
} 
Peraturan Menteri Lingkungan Hidup dan Kehutanan Republik Indonesia Nomor P.28/MENLHK/SETJEN/KUM.1/4/2017 Tentang Pedoman Penyusunan Formasi Jabatan Fungsional Pengawas Lingkungan Hidup, mengatur tentang Monitoring dan evaluasi penyusunan formasi Jabatan Fungsional Pengawas Lingkungan Hidup. Pasal 13 ayat:

(1) Monitoring dan evaluasi penyusunan formasi Jabatan Fungsional Pengawas Lingkungan Hidup dilakukan oleh:

a. Sekretaris Jenderal Kementerian Lingkungan Hidup dan Kehutanan;

b. Pimpinan Unit Kerja Eselon I di Kementerian Lingkungan Hidup dan Kehutanan yang membidangi Pengawas Lingkungan Hidup; dan

c. Pimpinan Unit Kerja di daerah yang membidangi pengawasan dampak lingungan;sesuai dengan kewenangan dan tanggung jawabnya.

(2) Monitoring sebagaimana dimaksud pada ayat (1) dilakukan untuk mengetahui pelaksanaan dan permasalahan yang dihadapi terhadap penyusunan formasi Jabatan Fungsional Pengawas Lingkungan Hidup

(3) Evaluasi sebagaimana dimaksud pada ayat

(1) dilakukan terhadap :

a. evaluasi instrumen penyusunan formasi Jabatan Fungsional Pengawas Lingkungan Hidup; dan

b. evaluasi kebutuhan formasi pada unit organisasi pengguna Jabatan Fungsional Pengawas Lingkungan Hidup.

Pasal 14. Pembiayaan penyusunan formasi Jabatan Fungsional Pengawas Lingkungan Hidup dibebankan pada :

a. anggaran pendapatan dan belanja negara;

b. anggaran pendapatan dan belanja daerah; dan/atau

c. sumber pembiayaan lainnya yang sah.

\section{B. Penetapan Pejabat Pengawas Lingkungan Hidup}

Undang-Undang Nomor 32 Tahun 2009 Tentang Perlindungan Dan Pengelolaan Lingkungan Hidup, mengatur mengenai Pengawasan sebagaimana dinyatakan pada Pasal 71 ayat:

Pejabat Pengawas Lingkungan Hidup Daerah (PPLHD) Diakses 3/21/2020 10:05 Wita.
(1) Menteri, gubernur, atau bupati/walikota sesuai dengan kewenangannya wajib melakukan pengawasan terhadap ketaatan penanggung jawab usaha dan/atau kegiatan atas ketentuan yang ditetapkan dalam peraturan perundang-undangan di bidang perlindungan dan pengelolaan lingkungan hidup.

(2) Menteri, gubernur, atau bupati/walikota dapat mendelegasikan kewenangannya dalam melakukan pengawasan kepada pejabat/instansi teknis yang bertanggung jawab di bidang perlindungan dan pengelolaan lingkungan hidup.

(3) Dalam melaksanakan pengawasan, Menteri, gubernur, atau bupati/walikota menetapkan pejabat pengawas lingkungan hidup yang merupakan pejabat fungsional.

Pasal 72. Menteri, gubernur, atau bupati/walikota sesuai dengan kewenangannya wajib melakukan pengawasan ketaatan penanggung jawab usaha dan/atau kegiatan terhadap izin lingkungan.

Pasal 73. Menteri dapat melakukan pengawasan terhadap ketaatan penanggung jawab usaha dan/atau kegiatan yang izin lingkungannya diterbitkan oleh pemerintah daerah jika Pemerintah menganggap terjadi pelanggaran yang serius di bidang perlindungan dan pengelolaan lingkungan hidup

Penjelasan Pasal 73 Yang dimaksud dengan "pelanggaran yang serius" adalah tindakan melanggar hukum yang mengakibatkan pencemaran dan/atau kerusakan lingkungan hidup yang relatif besar dan menimbulkan keresahan masyarakat.

Izin; pernyataan mengabulkan (tiada melarang dan sebagainya) persetujuan membolehkan. ${ }^{14}$ Izin adalah suatu persetujuan dari penguasa berdasarkan peraturan perundang-undangan dan peraturan pemerintah. Dengan demikian izin pada prinsipnya memuat larangan, persetujuan yang merupakan dasar pengecualian. Pengecualian itu harus diberikan oleh undang-undang untuk menunjukkan legalitas sebagai suatu ciri negara hukum yang demokrasi. ${ }^{15}$

\footnotetext{
${ }^{14}$ Sudarsono, Kamus Hukum, Cetakan Keenam, PT. Rineka Cipta, Jakarta, 2009, hlm. 189.

${ }^{15} \mathrm{H}$. Juniarso Ridwan dan Achmad Sodik Sudrajat, Hukum Adminsitrasi Negara dan Kebijakan Pelayanan Publik, Cetakan I. Nuansa. Bandung. 2010.hlm. 92.
} 
Izin (Vergunning) adalah suatu persetujuan dari penguasa berdasarkan undang-undang atau peraturan pemerintah untuk dalam keadaan tertentu menyimpang dari ketentuanketentuan larangan peraturan perundangundangan. Izin dapat juga diartikan sebagai dispensasi atau pelepasan/pembebasan dari suatu larangan. ${ }^{16}$

Perizinan adalah salah satu bentuk pelaksanaan fungsi pengaturan dan bersifat pengendalian yang dimiliki oleh pemerintah terhadap kegiatan-kegiatan yang dilakukan oleh masyarakat. Dengan memberikan izin, penguasa memperkenankan orang yang memohonnya untuk melakukan tindakantindakan tertentu yang sebenarnya dilarang demi memperhatikan kepentingan umum yang mengharuskan adanya pengawasan. Hal pokok pada izin, bahwa sesuatu tindakan dilarang kecuali diperkenankan dengan tujuan agar dalam ketentuan-ketentuan yang bersangkutan dilakukan dengan cara-cara tertentu. ${ }^{17}$

Dapat dikatakan dengan sangat tegas dalam Pasal 71 ayat (2) dan ayat (3) tentang pentingnya ketersedian Pejabat Pengawas Lingkungan Hidup (PPLH) yang ditetapkan oleh Menteri dan Pejabat Pengawas Lingkungan Hidup Daerah (PPLHD) yang ditetapkan oleh Gubernur/Bupati/Walikota sesuai dengan kewenangannya untuk dapat melaksanakan peran dan tugasnya. PPLH dan PPLHD seyongyanya memiliki kompetensi sebagai pengawas yaitu memiliki pengetahuan, keterampilan dan sikap yang sesuai dengan petunjuk tata laksana seorang pengawas yang ditetapkan dalam peraturan perundangundangan, untuk memiliki hal-hal tersebut diatas maka sebelum seseorang diangkat menjadi pejabat fungsional pengawas maka dia wajib untuk ikut pendidikan dan latihan untuk menjadi seorang pengawas. ${ }^{18}$

Peraturan Menteri Lingkungan Hidup dan Kehutanan Republik Indonesia Nomor P.28/MENLHK/SETJEN/KUM.1/4/2017 Tentang Pedoman Penyusunan Formasi Jabatan Fungsional Pengawas Lingkungan Hidup,

\footnotetext{
${ }^{16}$ Adrian Sutedi. Hukum Perizinan Dalam Sektor Pelayanan Publik, Sinar Grafika. Jakarta. 2011, hlm.167-168.

${ }^{17}$ Ibid, hlm. 168.

18 http://portal.bangkabaratkab.go.id/content/pejabatpengawas-lingkungan-hidup-daerah-pplhd?. Artikel. Pejabat Pengawas Lingkungan Hidup Daerah (PPLHD) Diakses 3/21/2020 10:05 Wita.
}

mengatur tentang Penyusunan Formasi Jabatan

Fungsional Pengawas Lingkungan Hidup.

Pasal 5 ayat:

(1) Setiap unit organisasi pengguna Jabatan Fungsional Pengawas Lingkungan Hidup wajib melakukan penyusunan formasi.

(2) Penyusunan formasi Jabatan Fungsional Pengawas Lingkungan Hidup sebagaimana dimaksud dalam Pasal 3 ayat (2) dilakukan melalui tahapan :

a. inventarisasi kegiatan;

b. penghitungan; dan

c. pemetaan struktur.

(3) Penyusunan Formasi Jabatan Fungsional Pengawas Lingkungan Hidup dilakukan setiap 5 (lima) tahun sekali atau sesuai dengan kebutuhan organisasi.

Pasal 6 ayat:

(1) Pimpinan unit organisasi melakukan inventarisasi kegiatan meliputi unsur, sub unsur, dan butir kegiatan, dari setiap tingkat dan jenjang Jabatan Fungsional Pengawas Lingkungan Hidup sesuai kebutuhan unit organisasi.

(2) Inventarisasi kegiatan setiap tingkat dan jenjang jabatan sebagaimana dimaksud pada ayat (1) memperhatikan tugas pokok unit organisasi, rencana strategis dan rencana kerja.

(3) Format inventarisasi kegiatan setiap tingkat dan jenjang jabatan sebagaimana dimaksud pada ayat (1) tercantum dalam Lampiran I yang merupakan bagian tidak terpisahkan dari Peraturan Menteri ini.

Peraturan Menteri Lingkungan Hidup dan Kehutanan Republik Indonesia Nomor P.28/MENLHK/SETJEN/KUM.1/4/2017 Tentang Pedoman Penyusunan Formasi Jabatan Fungsional Pengawas Lingkungan Hidup, Pasal 1 angka 7. Volume Kegiatan yang selanjutnya disingkat $(\mathrm{V})$ adalah volume masing-masing kegiatan yang dilaksanakan oleh Pengawas Lingkungan Hidup dalam 1 (satu) tahun. Pasal 1 angka 8. Waktu Penyelesaian Volume yang selanjutnya disingkat (Wpv) adalah waktu penyelesaian volume masing-masing kegiatan yang dilaksanakan oleh Pengawas Lingkungan Hidup dalam 1 (satu) tahun. Pasal 1 angka 9. Waktu Penyelesaian Butir Kegiatan yang selanjutnya disingkat (Wpk) adalah waktu yang dibutuhkan oleh Pengawas Lingkungan Hidup untuk menyelesaikan setiap butir kegiatan. 
Pasal 7 ayat:

(1) Berdasarkan hasil inventarisasi kegiatan sebagaimana dimaksud dalam Pasal 6, dihitung volume kegiatan (V) selama 1 (satu) tahun.

(2) Berdasarkan hasil penghitungan volume sebagaimana dimaksud pada ayat (1), dihitung waktu penyelesaian volume (Wpv) pada seluruh kegiatan.

(3) Penghitungan waktu penyelesaian volume (Wpv) sebagaimana dimaksud pada ayat (2) didasarkan pada waktu penyelesaian butir kegiatan (Wpk) yang ditetapkan oleh instansi pembina.

Pasal 8 ayat:

(4) Berdasarkan hasil penghitungan seluruh volume (Wpv) sebagaimana dimaksud dalam Pasal 7 ayat (3), pimpinan unit organisasi memperoleh jumlah kebutuhan formasi pada setiap tingkat dan jenjang Jabatan Fungsional Pengawas Lingkungan Hidup.

(5) Dalam hal penghitungan formasi Jabatan Fungsional Pengawas Lingkungan Hidup sebagaimana dimaksud pada ayat (2) memperoleh :

a. nilai di belakang koma kurang dari 50 (lima puluh), maka hasilnya dibulatkan ke bawah; atau

b. nilai dibelakang koma lebih besar atau sama dengan 50 (lima puluh), maka hasilnya dibulatkan ke atas.

Pasal 9 ayat:

(1) Metode penghitungan waktu penyelesaian volume (Wpv) dan penghitungan formasi Jabatan Fungsional Pengawas Lingkungan Hidup tercantum dalam Lampiran II yang merupakan bagian tidak terpisahkan dari Peraturan Menteri ini.

(2) Format blanko penghitungan formasi Jabatan Fungsional Pengawas Lingkungan Hidup tercantum dalam Lampiran III yang merupakan bagian tidak terpisahkan dari Peraturan Menteri ini.

Pasal 10 ayat:

(1) Hasil penghitungan jumlah kebutuhan formasi Jabatan Fungsional Pengawas Lingkungan Hidup setiap jenjang dituangkan dalam peta jabatan.

(2) Peta jabatan sebagaimana dimaksud pada ayat (1) untuk mengetahui kedudukan dalam organisasi, jumlah pemangku jabatan dan jumlah kebutuhan Jabatan Fungsional Pengawas Lingkungan Hidup.

(3) Format peta jabatan sebagaimana dimaksud pada ayat (2) tercantum dalam Lampiran IV yang merupakan bagian tidak terpisahkan dari Peraturan Menteri ini.

Penetapan Formasi Jabatan Fungsional Pengawas Lingkungan Hidup, diatur dalam Pasal 11. Hasil penyusunan formasi Jabatan Fungsional Pengawas Lingkungan Hidup ditetapkan oleh Pejabat Pembina Kepegawaian. Pasal 12. Pejabat Pembina Kepegawaian sebagaimana dimaksud dalam Pasal 11 menyampaikan hasil penetapan formasi Jabatan Fungsional Pengawas Lingkungan Hidup kepada Menteri yang menyelenggarakan urusan pemerintahan di bidang Aparatur Sipil Negara dengan ditembuskan kepada Instansi Pembina.

UU No 32/2009 tentang Perlindungan dan Pengelolaan Lingkungan Hidup yang dilahirkan pada masa reformasi yang mengatur:

1. Keutuhan unsur-unsur pengelolaan lingkungan hidup;

2. Kejelasan kewenangan antara pusat dan daerah;

3. Penguatan pada upaya pengendalian lingkungan hidup;

4. Penguatan instrumen pencegahan pencemaran dan/atau kerusakan lingkungan hidup, yang meliputi instrumen kajian lingkungan hidup strategis, tata ruang, baku mutu lingkungan hidup, kriteria baku kerusakan lingkungan hidup, Amdal, upaya pengelolaan lingkungan hidup dan upaya pemantauan lingkungan hidup, perizinan, instrumen ekonomi lingkungan hidup, peraturan perundang-undangan berbasis lingkungan hidup, anggaran berbasis lingkungan hidup, analisis risiko lingkungan hidup, dan instrumen lain yang sesuai dengan perkembangan ilmu pengetahuan dan teknologi;

5. Pendayagunaan perizinan sebagai instrumen pengendalian;

6. Pendayagunaan pendekatan ekosistem;

7. Kepastian dalam merespons dan mengantisipasi perkembangan lingkungan global;

8. Penguatan demokrasi lingkungan melalui akses informasi, akses partisipasi, dan akses keadilan serta penguatan hak-hak 
masyarakat dalam perlindungan dan pengelolaan lingkungan hidup;

9. Penegakan hukum perdata, administrasi, dan pidana secara lebih jelas;

10. Penguatan kelembagaan perlindungan dan pengelolaan lingkungan hidup yang lebih efektif dan responsif;

11. Penguatan kewenangan pejabat pengawas lingkungan hidup dan penyidik pegawai negeri sipil lingkungan hidup. ${ }^{19}$

Perjalanan panjang hukum mengenai lingkungan hidup di Indonesia seperti telah diuraikan sebelumnya tidak dapat dilepaskan dari unsur polit ik penguasa saat itu sehingga berimbas pada karakter produk hukum yang dihasilkan, khususnya mengenai hukum lingkungan di Indonesia.

Dalam Hukum Administrasi, izin merupakan instrumen yuridis yang digunakan oleh pemerintah untuk mempengaruhi para warga agar mau mengikuti cara yang dianjurkan guna mencapai suatu tujuan konkrit. Sebagai suatu instrumen hukum, izin berfungsi sebagai ujung tombak atau alat yang bertujuan untuk mengarahkan, mengendalikan, merekayasa, dan merancang masyarakat adil makmur. Melalui izin dapat diketahui bagaimana gambaran masyarakat adil makmur itu terwujud, yang berarti persyaratan-persyaratan yang terkandung dalam izin merupakan pengendali dalam memfungsikan izin itu sendiri. ${ }^{20}$ Izin dapat juga diartikan sebagai dispensasi atau pelepasan/pembebasan dari suatu larangan, sedangkan perizinan adalah salah satu bentuk pelaksanaan fungsi pengaturan dan bersifat pengendalian yang dimiliki oleh Pemerintah terhadap kegiatankegiatan yang dilakukan oleh masyarakat. ${ }^{21}$

\section{PENUTUP}

\section{A. Kesimpulan}

1. Kewenangan pejabat pengawas lingkungan hidup seperti melakukan pemantauan, meminta keterangan, membuat salinan dari dokumen dan/atau membuat catatan yang diperlukan, memasuki tempat tertentu, memotret,

\footnotetext{
${ }^{19}$ I. Putu Sastra Wibawa. Op.Cit. hlm. 57.

${ }^{20}$ Ridwan. HR. Hukum Administrasi Negara. UII Press. Yogyakarta. 2003. hlm. 160.

${ }^{21}$ Adrian Sutedi. Hukum Perizinan dalam Sektor Pelayanan Publik. Sinar Grafika. Jakarta. 2009. hlm. 167-168.
}

membuat rekaman audio visual, mengambil sampel, memeriksa peralatan, memeriksa instalasi dan/atau alat transportasi dan/atau menghentikan pelanggaran tertentu. Penanggung jawab usaha dan/atau kegiatan dilarang menghalangi pelaksanaan tugas pejabat pengawas lingkungan hidup.

2. Penetapan Pejabat Pengawas Lingkungan hidup dilaksanakan oleh Menteri, gubernur, atau bupati/walikota sesuai dengan kewenangannya wajib melakukan pengawasan terhadap ketaatan penanggung jawab usaha dan/atau kegiatannya dan pengawasan kepada pejabat/instansi teknis termasuk menetapkan pejabat pengawas lingkungan hidup yang merupakan pejabat fungsional dalam perlindungan dan pengelolaan lingkungan hidup.

\section{B. Saran}

1. Dalam melaksanakan kewenangannya pejabat pengawas lingkungan hidup perlu melakukan koordinasi dengan pejabat penyidik pegawai negeri sipil yang berwenang melakukan pemeriksaan atas kebenaran laporan atau keterangan berkenaan dengan tindak pidana di bidang perlindungan dan pengelolaan lingkungan hidup sebagaimana diatur dalam Undang-Undang Nomor 32 Tahun 2009 Tentang Perlindungan dan Pengelolaan Lingkungan Hidup.

2. Dalam melakukan pengawasan terhadap perlindungan dan pengelolaan lingkungan hidup oleh Menteri, gubernur, atau bupati/walikota sesuai dengan kewenangannya apabila menemukan adanya pelanggaran terhadap izin lingkungan, maka diperlukan pemberlakuan sanksi administratif seperti teguran tertulis; paksaan pemerintah; pembekuan izin lingkungan; atau pencabutan izin lingkungan.

\section{DAFTAR PUSTAKA}

Hadari Nawawi. Pengawasan Melekat di Lingkungan Aparatur Pemerintah. Gelora Aksara Pratama, Jakarta. 1992. 
Hadjon M. Philipus. dkk. Pengantar Hukum Administrasi Indonesia, Gadjah Mada Press University Yogyakarta. 2002.

Hardjasoemantri Koesnadi, Hukum Tata Lingkungan, Edisi Kedelapan, Cetakan Kedelapanbelas, Gajah Mada University Press, Yogyakarta, 2005.

Hariri Muhwan Wawan. Pengantar Ilmu Hukum, Cet. 1. CV. Pustaka Setia Bandung. 2012.

HR.Ridwan. Hukum Administrasi Negara. UII Press. Yogyakarta. 2003.

Husni Lalu, Pengantar Hukum Ketenagakerjaan Indonesia, Edisi Revisi, PT. RajaGrafindo, Jakarta, 2008.

Machmud Syahrul. Penegakan Hukum Lingkungan Indonesia. (Penegakan Hukum Administrasi. Hukum Perdata. Dan Hukum Pidana Menurut UndangUndang No. 32 Tahun 2009) Graha Ilmu. Yogyakarta.Graha IImu, Bandung. 2012.

Marbun Rocky, Deni Bram, Yuliasara Isnaeni dan Nusya A., Kamus Hukum Lengkap (Mencakup Istilah Hukum \& Perundang-Undangan Terbaru, Cetakan Pertama, Visimedia, Jakarta. 2012.

Muhamad Erwin, Hukum Lingkungan Dalam Sistem Kebijaksanaan Pembangunan Lingkungan Hidup, Cetakan Kedua. PT. Refika Aditama, April 2009.

Nurdin M.. Peranan Penyidik Dalam Penegakan Hukum Terhadap Pelanggaran Tindak Pidana Lingkungan Hidup. Jurnal Hukum Samudra Keadilan. Volume 12, Nomor 2, Juli-Desember 2017.

Prins W.F dan R. Kosim Adisapoetra, Pengantar Hukum IImu Administrasi Negara. Pradnya Paramita, Jakarta. 1983.

Putu Sastra Wibawa I.. Politik Hukum Perlindungan Dan Pengelolaan Lingkungan Menuju Ekokrasi Indonesia (Legal Politic of Protection And Management Oenvironment Heading To Indonesia Ecocracy). Kanun Jurnal Ilmu Hukum.Vol. 18, No. 1, (April, 2016), pp. 51-68.

Rangkuti Sundari Siti. Hukum Lingkungan dan Kebijaksanaan Lingkungan Nasional. Airlangga University Press. Surabaya. 2010.
Ridwan Juniarso H. dan Achmad Sodik Sudrajat, Hukum Adminsitrasi Negara dan Kebijakan Pelayanan Publik, Cetakan I. Nuansa. Bandung. 2010.

Sarwoto. Dasar-dasar Organisasi dan Manajemen, Ghalia Indonesia. Jakarta. 1994.

Sastrawijaya Tresna, Pencemaran Lingkungan, Cet. 2. Rineka Cipta, Jakarta, 2009.

Spelt N.M. dan J.B.J.M. Ten Berge, Pengantar Hukum Perizinan, (Penyunting) Philipus. M. Hadjon, Yuridika. Surabaya. 1993.

Sudarsono, Kamus Hukum, Cetakan Keenam, PT. Rineka Cipta, Jakarta, 2009.

Sutedi Adrian. Hukum Perizinan Dalam Sektor Pelayanan Publik, Sinar Grafika. Jakarta. 2011.

Sutedi Adrian. Hukum Perizinan dalam Sektor Pelayanan Publik. Sinar Grafika. Jakarta. 2009.

Usman, Aspek-Aspek Hukum Perbankan di Indonesia. Penerbit Gramedia Pustaka Utama. Jakarta. 2001.

\section{Peraturan Perundang-Undangan}

Undang-Undang Nomor 32 Tahun Tahun 2009 Tentang Perlindungan Dan Pengelolaan Lingkungan Hidup.

Peraturan Menteri Lingkungan Hidup Dan Kehutanan Republik Indonesia Nomor P.28/MENLHK/SETJEN/KUM.1/4/2017 Tentang Pedoman Penyusunan Formasi Jabatan Fungsional Pengawas Lingkungan Hidup.

\section{Internet}

http://portal.bangkabaratkab.go.id/content/pej abat-pengawas-lingkungan-hidup-daerahpplhd?. Artikel. Pejabat Pengawas Lingkungan Hidup Daerah (PPLHD) Diakses 3/21/2020 10:05 Wita.

http://pn-

ponorogo.go.id/joomla/index.php/artikelumum/49-perkembangan-hukum-lingkungandi-indonesia.html. Diakses 3/21/2020 9:55 Wita. 